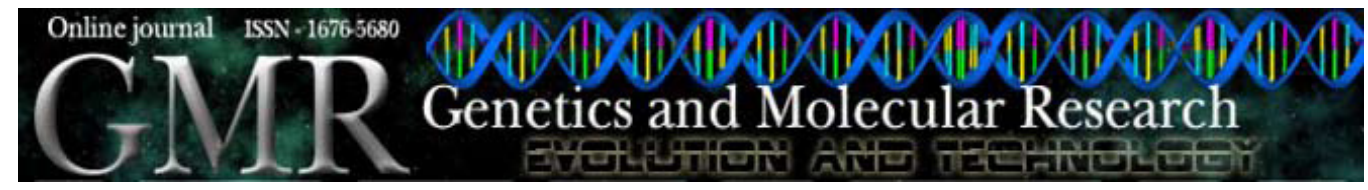

\title{
Obese gene polymorphism in Pietrain and Large White pigs after a divergent selection
}

\author{
A.C.P. Silveira ${ }^{1}$, R.C. Antunes ${ }^{1}$, J.F. Almeida ${ }^{2}$, T.F. Braga ${ }^{1}$, \\ P.F.A. Freitas ${ }^{1}$, A.S.M. César ${ }^{1}$ and E.C. Guimarães ${ }^{1}$ \\ ${ }^{1}$ Programa de Pós-Graduação em Ciências Veterinárias, \\ Faculdade de Medicina Veterinária, \\ Universidade Federal de Uberlândia, Uberlândia, MG, Brasil \\ ${ }^{2}$ Laboratório de Genética Molecular, \\ Universidade Federal de Uberlândia, \\ Instituto de Genética e Bioquímica, Uberlândia, MG, Brasil \\ Corresponding author: A.C.P. Silveira \\ E-mail: anacarolina@medicaveterinaria.com
}

Genet. Mol. Res. 7 (4): 1217-1222 (2008)

Received August 27, 2008

Accepted September 17, 2008

Published November 4, 2008

\begin{abstract}
The aim of the present study was to identify polymorphisms in the leptin gene of 112 pigs and compare the maternal and paternal lineage of Pietrain and Large White breeds that underwent a divergent selection for over 30 years. DNA samples extracted from the blood of these animals were amplified by polymerase chain reaction and genotyped by restriction fragment length polymorphism using the restriction enzyme HinfI. The data were statistically analyzed by the chi-square test. The results showed that $87.5 \%$ of the animals were genotype TT, where $31.25 \%$ were Large White paternal lineage, $31.25 \%$ were Pietrain paternal lineage and $25 \%$ were Pietrain maternal lineage. The TC genotype appeared in $12.5 \%$, where $10 \%$ were Large White, $0.5 \%$ were Pietrain paternal lineage and $2 \%$ were of the same maternal lineage breed; $\mathrm{CC}$ was not observed. As for the allele frequency, $93.75 \%$ of the $\mathrm{T}$ and $6.25 \%$ of the $\mathrm{C}$ allele were found. In Pietrain maternal and paternal lineages, it could not be determined that the Obese gene had been fixed in the maternal lineage. However, in the Pietrain and Large White paternal lineages there was a statistically significant difference,
\end{abstract}


suggesting that the $\mathrm{C}$ allele is associated with growth and daily weight gain and that the low frequency of $\mathrm{C}$ in the Pietrain lineage is related to low rate of body fat, a typical feature of this breed.

Key words: Quantitative trait loci; Leptin; Polymerase chain reaction; Obese gene; Restriction fragment length polymorphism

\section{INTRODUCTION}

In pigs, the Obese gene (or leptin gene) is considered to be an eligible gene to follow characteristics of economic importance, such as feed intake, pig fat thickness, growth, and reproduction (Lagonigro et al., 2003). The search for polymorphism in this gene is aimed at responding if the alterations found may be correlated to productive and reproductive features. In this species, seven leptin gene polymorphisms were described: C/T, A/G, C/T, G/T, A/T, $\mathrm{T} / \mathrm{C}$, and G/A at the following positions: 867, 1112, 3469, 3714, 2845, 3996, and 2728, respectively (Stratil et al., 1997; Robert et al., 1998; Jiang and Gibson, 1999; Kennes et al., 2001). Researchs such as those of Robert et al. (1998) and Jiang and Gibson (1999) suggest a relation between polymorphism and the features of economic interest. Others have found little or no statistical significance among them (Malek et al., 2001; Kennes et al., 2001; Szydlowski et al., 2004; Terman, 2005). de Oliveira Peixoto et al. (2006) affirm that the individual contribution of the leptin gene to productive and reproductive feature is still unknown, since growth and carcass composition are controlled by various genes and influenced by the environment.

Generally, the strategy adopted by laboratories for quantitative trait locus linking, analysis and detection map construction explores genetic and phenotype divergence among pig breeds. The breeds used for cross-reference are of three types: European or American commercial breeds (Large White, Landrace and/or Pietrain), Chinese breeds (mainly Meishan) and the wild European pig (Ellegren, 1995; Reis Filho, 2007).

Therefore, in this study, Pietrain breed was used, whose paternal genetic lineage improvement resulted from the necessity of an even more carcass quality-requiring market, showing as constitutional advantages: lower fat rate and body fat thickness, excellent fore and hind legs and a larger loin, and due to the growing use of pig husbandry technology and labor force reduction, research also focuses on the maternal ability development of the breed, such as maternal docility, high milk production and piglet vitality (Porter, 1993). Large White is the breed that offers the largest daily weight gain, reaching $90 \mathrm{~kg}$ at a lower age compared to Pietrain (Tibau et al., 1997), when fast and slow growth lineages, respectively, were considered.

The aim of the present study was to identify and compare Obese gene polymorphism frequency in paternal and maternal lineages of Pietrain breed and in Pietrain and Large White paternal lineages, which have undergone divergent selection for over 30 years.

\section{MATERIAL AND METHODS}

\section{Biological material and sample collection}

Blood samples were collected from the jugular vein of 112 pigs, where 36 were Pietrain paternal lineage ( 8 males and 28 females), 30 were Pietrain maternal lineage (11 males 
and 19 females) and 46 Large White paternal lineage (11 males and 35 females); all supplied by the nucleus farm of a breeding company, located in Rio Verde, Goiás, Brazil.

\section{Genotyping at the Obese locus}

Genotyping at the Obese gene was performed on animal blood by polymerase chain reaction (PCR)-restriction fragment length polymorphism, according to Stratil et al. (1997), using a pair of primers with the following sequences: 5'TGCAGTCTGTCTCCTCCAAA3' (forward) and 5'CGATAATTGGATCACATTTCTG3' (reverse), which amplifies an amplicon of $152 \mathrm{bp}$. PCR was carried out in a PTC-MJ Research thermocycler. After preheating at $95^{\circ} \mathrm{C}$ for $2 \mathrm{~min}$, amplification was done using 34 cycles at $95^{\circ} \mathrm{C}$ for $1 \mathrm{~min}, 55^{\circ} \mathrm{C}$ for $1 \mathrm{~min}$, and $72^{\circ} \mathrm{C}$ for $1 \mathrm{~min}$. For the PCR assays, $1 \mathrm{U}$ Taq DNA polymerase, 10X PCR buffer, $3.0 \mathrm{mM} \mathrm{MgCl}$, $200 \mu \mathrm{M}$ of each dNTP, $10 \mathrm{pM}$ of each primer and $200 \mathrm{ng}$ genomic DNA in a final volume of $20 \mu \mathrm{L}$ were used. After amplification, $10 \mu \mathrm{L}$ of the PCR amplicon was digested with $2 \mathrm{U}$ HinfI restriction enzyme for $8 \mathrm{~h}$ at $37^{\circ} \mathrm{C}$; genotyping was performed on a $3.5 \%$ agarose gel stained with ethidium bromide $(10 \mathrm{mg} / \mathrm{mL})$ and photographed under UV illumination.

\section{Statistical analysis}

The genotypes obtained were statistically analyzed by the $\chi^{2}$ (chi-square) test at a significance level of 0.05 .

\section{RESULTS}

\section{Genotyping at the Obese locus}

Figure 1 shows the genotype patterns. Allele T contained one 152-bp fragment, whereas allele $\mathrm{C}$ had two fragments ( 84 and $68 \mathrm{bp}$ ).

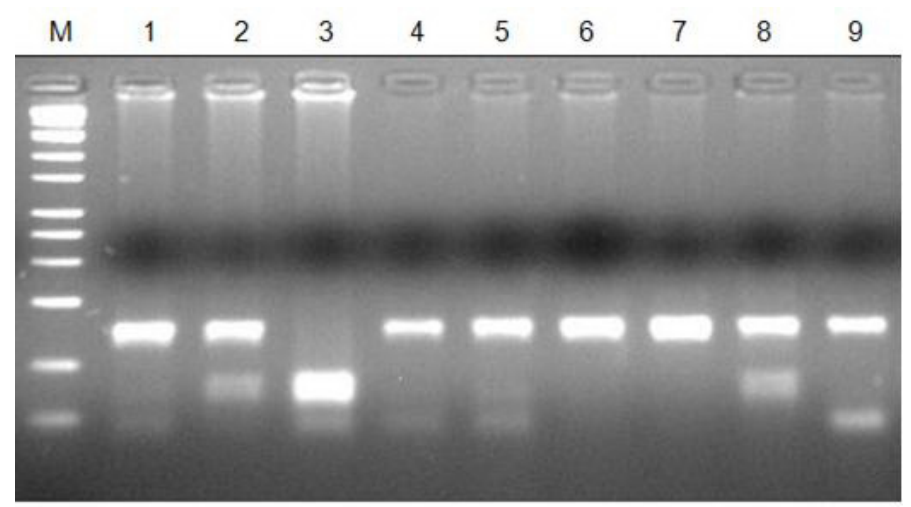

Figure 1. HinfI polymorphisms in the Obese gene detected by polymerase chain reaction-restriction fragment length polymorphism (PCR-RFLP). The PCR products were run on a $3.5 \%$ agarose gel. $\mathrm{M}=50$-bp ladder of molecular weight markers (Invitrogen); lane 1 = TT genotype pattern sample; lane $2=$ TC genotype pattern sample; lane $3=$ CC genotype pattern sample; lanes 4-6, 7, 9 = TT samples; lane $8=$ TC sample. 


\section{Allele genotype frequencies}

After genotyping the 112 Large White pigs (paternal lineage) and Pietrain (maternal and paternal lineages), the genotype (Table 1) frequencies and the Obese gene allele frequency (Table 2) were determined. When comparing the genotype frequency of paternal and maternal Pietrain lineages, statistically significant differences were not found $(P>0.05$.) However, when analyzing the paternal Pietrain and Large White lineages, statistically significant differences were found $(\mathrm{P}<0.05)$.

\begin{tabular}{l} 
Table 1. Determination of Obese gene genotype frequency of 112 Pietrain breed pigs (maternal and paternal \\
lineages) and Large White (paternal lineage). \\
\hline \begin{tabular}{lcccccccc}
\hline Breed & \multicolumn{7}{c}{ Genotype frequency } \\
\cline { 2 - 9 } & TC & $(\%)$ & TT & $(\%)$ & CC & $(\%)$ & Total & $(\%)$ \\
\hline Pietrain (maternal lineage) & 2 & $(1.8 \%)$ & 28 & $(25 \%)$ & 0 & $(0 \%)$ & 30 & $(26.8 \%)$ \\
Pietrain (paternal lineage) & 1 & $(0.9 \%)$ & 35 & $(31.25 \%)$ & 0 & $(0 \%)$ & 36 & $(32.15 \%)$ \\
Large White (paternal lineage) & 11 & $(9.8 \%)$ & 35 & $(31.25 \%)$ & 0 & $(0 \%)$ & 46 & $(41.05 \%)$ \\
Total & 14 & $(12.5 \%)$ & 98 & $(87.5 \%)$ & 0 & $(0 \%)$ & 112 & $(100 \%)$ \\
\hline
\end{tabular}
\end{tabular}

Table 2. Determination of Obese gene allele frequency of 112 Pietrain breed pigs (maternal and paternal lineages) and Large White (paternal lineage).

\begin{tabular}{lrrrrrr}
\hline Breed & \multicolumn{5}{c}{ Allele frequency } \\
\hline & \multicolumn{1}{c}{$\mathrm{T}$} & $(\%)$ & $\mathrm{C}$ & $(\%)$ & Total & $(\%)$ \\
\cline { 2 - 7 } & 58 & $(25.9 \%)$ & 2 & $(0.9 \%)$ & 60 & $(26.8 \%)$ \\
Pietrain (maternal lineage) & 71 & $(31.7 \%)$ & 1 & $(0.45 \%)$ & 72 & $(32.15 \%)$ \\
Pietrain (paternal lineage) & 81 & $(36.15 \%)$ & 11 & $(4.9 \%)$ & 92 & $(41.05 \%)$ \\
Large White (paternal lineage) & 210 & $(93.75 \%)$ & 14 & $(6.25 \%)$ & 224 & $(100 \%)$ \\
Total & & & & & & \\
\hline
\end{tabular}

\section{DISCUSSION}

The genotype frequencies observed were consistent with those reported by Borges and Goulart (2002) who, when genotyping 80 Large White pigs, observed $82.5 \%$ TT, $17.5 \%$ TC and no CC, and when analyzing 53 Pietrain animals, found $90.56 \%$ TT genotypes, $7.54 \%$ TC and $1.88 \%$ CC. The same allele frequencies were found by Borges and Goulart (2002), Stratil et al. (1997), Korwin-Kossakowska et al. (2001), Kulig et al. (2001), and Szydlowski et al. (2004) when studying other pig breeds.

Since no statistically significant difference was found between Pietrain breed maternal and paternal lineage genotypes, it is not possible to affirm that the Obese gene has been fixed more frequently on the maternal lineage than on the paternal lineage. The Obese gene was believed to be more often fixed on the maternal lineage, since due to the growing use of pig husbandry technology and the reduction in labor force, research has focused on ability development such as high milk production, which is related to body fat in female pigs (Porter, 1993), and on the fact that Chinese hyper-proliferative breeds such as Meishan are obese, while in the paternal lineage a lower fat rate and body fat thickness is desired (Porter, 1993). 
Jiang and Gibson (1999) found a positive correlation between C allele and the body fat rate in the Meishan breed. Borges and Goulart (2002) suggested that the $C$ allele may be associated with fat accumulation. Later, Kuryl et al. (2003) concluded that the TT genotype may be more advantageous since it is associated with lower fat deposition in carcass when compared to TC. The research of Urban et al. (2002) demonstrated that in Landrace breed animals, the homozygote (TT) showed a lower daily weight gain compared to the heterozygote (TC).

The differences between the paternal and maternal lineages of pigs impact the growth and development of these animals, which may be mediated by the metabolism and partition of nutrients between fat and muscle tissues (Sinclair et al., 1998). These energy metabolism variations may be attributed, in part, to the endocrine profile of the different maternal and paternal lineages and environmental conditions (Leininger et al., 2000.) Litten et al. (2004) argue that differences in growth, feed intake and carcass quality between maternal and paternal lineages of pig breeds are mainly due to genetics, with little influence of the endocrine factors of such animals.

Yet the higher $\mathrm{C}$ allele frequency found in Large White paternal lineage in relation to the Pietrain paternal lineage suggests that this is linked to growth and daily weight gain, since the growth of Large White is considered to be fast, while that of the Pietrain is slow. Houseknecht et al. (1998) argue that feed intake regulation and the energy balance in the body are important in optimizing animal growth. Moreover, the fact that leptin regulates growth hormone secretion by stimulating it has been observed (Barb et al., 1998.)

The Large White breed is also associated with high prolificacy (Porter, 1993) and best average daily weight gain (Pires et al., 2002.) It is, therefore, possible that the $\mathrm{C}$ allele is related to growth and daily weight gain and that no significant difference between maternal and paternal lineages of Pietrain was found due to the size of the sample. However, Szydlowski et al. (2004) found no association between R3469C polymorphism of the leptin gene and intramuscular fat characteristics in Large White when analyzing 135 animals.

It is possible that the low $\mathrm{C}$ allele frequency in Pietrain is linked to breed characteristics, cited by Rothschild and Ruvinsky (1998) as the high percentage of lean meat, low fat rates, high loin thickness, and greater conformation of carcass in hind legs. Also, Gregory et al. (1977) found higher circulating levels of insulin in Large White pigs than in Pietrain, which are more sensitive to stress and are producers of greater lean mass.

de Oliveira Peixoto et al. (2006) cited two cases that enable an associated explanation between the leptin gene and productive and reproductive characteristics in pigs. The first suggests that the detected polymorphisms are in imbalance with another single nucleotide polymorphism, which could be the true cause of the observed variations. The second states that there may be false positives for a limited number of observations of some genotypes or combinations.

\section{CONCLUSIONS}

The divergent selection of Pietrain breed maternal and paternal lineages did not alter the genotype and allele frequency of the Obese gene, as well as between genders. However, among Large White and Pietrain breed paternal lineages, the $\mathrm{C}$ allele was better fixed in the latter, suggesting that it is linked to growth and daily weight gain or that the lower frequency found in Pietrain correlates with its characteristics. 


\section{REFERENCES}

Barb CR, Yan X, Azain MJ, Kraeling RR, et al. (1998). Recombinant porcine leptin reduces feed intake and stimulates growth hormone secretion in swine. Domest. Anim. Endocrinol. 15: 77-86.

Borges GSN and Goulart LR (2002). Influence of obesity gene in quantitative traits of swine. Genet. Mol. Biol. 25: 29-35.

de Oliveira Peixoto J, Facioni Guimaraes SE, Savio LP, Menck Soares MA, et al. (2006). Associations of leptin gene polymorphisms with production traits in pigs. J. Anim. Breed. Genet. 123: 378-383.

Ellegren H (1995). Mutation rates at porcine microsatellite loci. Mamm. Genome 6: 376-377.

Gregory NG, Lovell RD, Wood JD and Lister D (1977). Insulin-secreting ability in Pietrain and Large White pigs. $J$. Agric. Sci. 89: 407-413.

Houseknecht KL, Baile CA, Matteri RL and Spurlock ME (1998). The biology of leptin: a review. J. Anim. Sci. 76: 1405-1420.

Jiang ZH and Gibson JP (1999). Genetic polymorphisms in the leptin gene and their association with fatness in four pig breeds. Mamm. Genome 10: 191-193.

Kennes YM, Murphy BD, Pothier F and Palin MF (2001). Characterization of swine leptin (LEP) polymorphisms and their association with production traits. Anim. Genet. 32: 215-218.

Korwin-Kossakowska A, Kamyczek M, Ciéslak D and Kury J (2001). The polymorphism of reproduction-linked genes in Line 990 sows. Anim. Sci. Pap. Rep. 19: 265-274.

Kulig H, Grezesiak W and Szatkowska I (2001). Effect of leptin gene polymorphism on growth and carcass traits in pigs. Arch. Tierz. Dummerstorf. 44: 291-296.

Kuryl YM, Murphy BD, Pierzchala M, Bocian M, et al. (2003). A relationship between genotypes at the GH and LEP loci and carcass meat and fat deposition in pigs. Anim. Sci. Pap. Rep. 21: 15-26.

Lagonigro R, Wiener P, Pilla F, Woolliams JA, et al. (2003). A new mutation in the coding region of the bovine leptin gene associated with feed intake. Anim. Genet. 34: 371-374.

Leininger MT, Portocarrero CP, Schinckel AP, Spurlock ME, et al. (2000). Physiological response to acute endotoxemia in swine: effect of genotype on energy metabolites and leptin. Domest. Anim. Endocrinol. 18: 71-82.

Litten JC, Corso AM, Hall AD and Clarke L (2004). The relationship between growth performance, feed intake, endocrine profile and carcass quality of different maternal and paternal lines of pigs. Livest. Prod. Sci. 89: 33-39.

Malek M, Dekkers JC, Lee HK, Baas TJ, et al. (2001). A molecular genome scan analysis to identify chromosomal regions influencing economic traits in the pig. I. Growth and body composition. Mamm. Genome 12: 630-636.

Pires AV, Fonseca R, Cobuci JA, Araújo CV, et al. (2002). Genetic divergence study among Duroc, Landrace and Large White swine breeds using techniques of multivariate analysis. Arch. Latinoam. Prod. Anim. 10: 81-85.

Porter V (1993). PIGS: A Handbook of the Breeds of the World. Cornell University, New York, 128-130.

Reis Filho JC (2007). Proposta de avaliação genética de suínos obtidos por cruzamentos entre raças nativas e comerciais. Suíno.com: Comunidade de Genética, [http://www.suino.com.br/genetica/noticia.asp?pf_id=32138\&dept_id=5]. Accessed February 13, 2008.

Robert C, Palin MF, Coulombe N, Roberge C, et al. (1998). Backfat thickness in pigs is positively associated with leptin mRNA levels. Can. J. Anim. Sci. 78: 473-482.

Rothschild MF and Ruvinsky A (1998). The Genetics of the Pig. CAB International, Wallingford, Oxon.

Sinclair AG, Cia MC, Edwards SA and Hoste S (1998). Response to dietary protein during lactation of Meishan synthetic, Large White and Landrace gilts given food to achieve the same target backfat level at farrowing. Anim. Sci. 67: 349-354.

Stratil A, Peelman L, Van Poucke M and Cepica S (1997). A HinfI PCR-RFLP at the porcine leptin (LEP) gene. Anim. Genet. 28: 371-372.

Szydlowski M, Stachowiak M, Mackowski M, Kamyczek M, et al. (2004). No major effect of the leptin gene polymorphism on porcine production traits. J. Anim. Breed. Genet. 121: 149-155.

Terman A (2005). Effect of the polymorphism of prolactin receptor (PRLR) and leptin (LEP) genes on litter size in Polish pigs. J. Anim. Breed. Genet. 122: 400-404.

Tibau J, Puigvert X, Soler J, Trilla N, et al. (1997). Incidencia de factores geneticos y de comportamiento en la eficiencia del crecimiento, la composicion y la calidad de la canal y de la carne en distintas razas porcinas. Anaporc 171: 74-91.

Urban T, Kuciel J and Mikolásóvá R (2002). Polymorphism of genes encoding for ryanodine receptor, growth hormone, leptin and MYC protooncogene protein and meat production in Duroc pigs. Czech J. Anim. Sci. 47: 411-417. 